\title{
LANDSCAPE AND GODS AMONG THE KHANTY
}

\author{
ART LEETE \\ Professor of Ethnology \\ University of Tartu \\ Ülikooli 18, 50090 Tartu, Estonia \\ e-mail: art.leete@ut.ee
}

\begin{abstract}
The purpose of this article* is to examine Khanty spatial ritual behaviour in the context of the simultaneous application of different ideas about sacred landscape. I aim to demonstrate the functional pattern behind handling seemingly ambivalent characteristics of cosmological models in the tangible ritual performance of the Khanty, an indigenous people inhabiting the taiga and forest taiga zone of Western Siberia. I explore three cases in which the concept of sacred topography is applied among the Khanty by exploring two public ceremonies of reindeer sacrifice and one episode of a post-funeral rite. It appeared that the spatial conceptualisation is different in different rituals. During sacrificial ceremonies, the Khanty position the Upper World in the southern direction, while in the case of death rituals, the Upper World is projected towards upstream of a river, even if it remains in the north. Studying different spatial orientations during rituals provides a methodological key for approaching other concepts of vernacular belief among Siberian indigenous communities.
\end{abstract}

KEYWORDS: the Khanty $\bullet$ reindeer $\bullet$ sacrifice $\bullet$ ritual $\bullet$ landscape $\bullet$ sacred topography $\bullet$ worldview

\section{IN T RODUCTION}

Many scholars argue that (folk) beliefs have ambivalent effects on people's social life and narrative practices. The contradictory nature of religion can appear, for example, in the course of social change (Appleby 2000; Gottowik 2014) but it can also be revealed in mythological narratives (Lunaček 2004) or in connection to the environment (Taringa 2006). In addition, it has been claimed that folk religion as a whole is heterogenic, illogical and contradictory (Valk 2008: 381) in its approach to the sacred landscape (Anttonen 1996: 108-125, 135-137).

In this paper I aim to discuss the ways in which the Khanty, the indigenous people of Western Siberia, manage their spatial ritual behaviour. The need for ritual management of space appears both in everyday life and rituals. The Khanty always keep in their mind the cardinal directions and the qualities of the landscape as this awareness ena-

* This research has been supported by the Estonian Research Council's grant no. PUT590 and the ERA.Net RUS Plus program's project no. 189 (CORUNO). 
bles them to manifest and apply simultaneously practical and spiritual topographical frames. In structuring space, myths and everyday deeds meet in very general attitudes and particular situations, in vague feelings and particular rules.

Myths codify worldview by being structural manifestations of distinguished archaic layers of culture. Myths represent tenacious cultural representations while at the same time also changing under pressure of dynamic social context. Myths constitute basic identity, a symbolic model of cultural totality, an integrated whole of visions of the world and meaningful elements of culture. (Siikala 2002: 15-17; 2012: 17-19)

For Claude Lévi-Strauss, myth is "a form of language" that directs people to comprehend dialectics and dichotomies of the surrounding world (Doniger 1995: viii). At the same time, Lévi-Strauss used myths in order to illuminate metaphorically human ambivalence and existential paradoxes (ibid.: x). According to Lévi-Strauss (1995 [1979]: $3)$, illiterate people grasp the meanings of myths intuitively in their lived experience. Indigenous people attempt to reach overall and complete understanding of the world by myths that enable the shortest way to comprehend the universe in a holistic mode (ibid.: 17, 44-45). Departing from the ideas of Lévi-Strauss, one can argue that myths relate to landscape as all-inclusive spatial experience.

Anna-Leena Siikala claims that myths not only manifest the core of culture in an abstract way. Certain social mechanisms enable myths to constitute actual cultural practices:

Their meanings emerge from a process of interpretation in which the symbolism of the cosmos, and the nature of the otherworld and human kind, is filtered through an individual culture, the reality subsiding within the consciousness of the community and of the person, and its flip-side, a second reality. (Siikala 2012: 19)

This discussion resembles Bronislaw Malinowski's (1954 [1926]: 100) functional approach, which says that a myth is "reality lived" and continuously influences human destinies in indigenous communities. Siikala stresses ambivalent rationality behind the functioning of myths. The actuality of ancient myths persists only in certain conditions and is based on "the logic of the impossible". This dialectic of reason and unfeasibility makes them comprehensible and influential. (Siikala 2012: 19)

The modern Khanty rather commonly accept mythical world perception. ${ }^{1}$ The dialogue between daily conduct and ritual actions reflects the functionality of the mythic world order in tangible cultural practices. "In codifying the structures of a worldview, myths carry the thought patterns of the past" (Siikala 2012: 22). Mythic imagination helps the Khanty to bridge experiential conflict between the traditional and modern realities of life.

Emphasising existential features of the myth enables a synthesis of Lévi-Strauss' approach to myth and functional tactic, as advocated by Malinowski (Harwood 1976: 784). Malinowski argues that myths are closely connected to understanding of the world and sacred tales, rituals and everyday actions. Myth enriches and arranges belief, thus empowering human existence. (Malinowski 1954 [1926]: 96-101; see also Harwood 1976: 784-785)

Malinowski also addresses the issue of the "enlivening influence of myth upon the landscape" (Malinowski 1922: 330). Landscape testifies the truth of the myth, makes it tangible and durable because the myth is fixed in it. Loaded with sacred connotations, 
landscape embodies a meaningful scene of actions. Tim Ingold (2002: 42) suggests that hunters take "the human condition to be that of a being immersed from the start, like other creatures, in an active, practical and perceptual engagement with constituents of the dwelt-in world." In Ingold's view, hunters apprehend the world through engagement, dwelling and "taking up a view in it" (ibid.).

Philippe Descola maintains that in order to reveal the indigenous mode of constructing representations of the environment, local concepts about cosmologies, ontologies, spatial representations and rituals must be taken into account. At the same time, Descola (2004: 85-86) admits that there is no "coherent and systematic corpus of ideas" available for discovery. Many members of observed native communities are not aware of the underlying doctrines of their cultural rules. Anthropologists reconstruct indigenous spatial models of ritual practice from fragments of narratives and seemingly trivial acts "which they weave together so as to produce meaningful patterns" (ibid.).

Dialogic association between the environment and humans, i.e. the practice of generalised reciprocity, is often metaphorically exemplified in terms of close, personal interaction (Pálsson 2004: 65, 72, 77). Embracing the dialogic perspective on ritual and the environment indicates a realistic existential position (ibid.: 78). Established practices of environmental interaction produce a sacred spatial dialogue, while collective ideologies enable it to be maintained (Ellen 2004: 103). But that coherent conceptual space cannot be adequately constructed on the basis of individual representations. People generate vague, irregular and ambiguous concepts of environment at the levels of individual practice and collective representations. (Ibid.: 104)

The understanding of myths, rituals and the landscape connects big cosmological schemes and people's everyday lives. Mythical images, intimate feelings and cultural practices meet at this existential and conceptual crossroads. Overall understanding of the world is shaped by cultural habits, although at the same time this understanding directs these practices in accordance with sacred rules. There is no undisputed understanding inside indigenous groups concerning the way in which sacred rules must be managed. This makes it rather complicated to draw general cultural schemes of the relationships between people, ritual and landscape.

Khanty rituals as well as sacred topography ${ }^{2}$ have been described multiple times in scholarly literature. Scholars have noted that for local spirits the Khanty have special sacred places where they can make sacrifices. Rituals of honouring the main gods can be made in different sacred places all over Western Siberia (Karjalainen 1900: 31, 35-38; Sirelius 1900: 23-24; Kulemzin 1984: 48-51; Rombandeyeva 1993: 60-64; Sokolova 2009: 594-607). The intimate connection between people, ritual and the landscape has been especially rarely discussed.

During the 1990s I performed ethnographic fieldwork among the Khanty annually. ${ }^{3}$ Even without specific enquiry, the topic of sacred topography popped up frequently. The Khanty must continually consider cardinal directions when moving around in a seasonal forest camp (in order not to anger gods or spirits), but more particularly, during performance of sacrificial rituals. Already during my first field trip it became quickly clear that Khanty life is constantly guided by considerations related to this sacred geography. Daily life illustrates the holistic effect of sacred rules among the Khanty, although the few collective sacrificial rituals I have conducted have been decisive in understanding the principal importance of sacred topography for the Khanty. 
In addition, while studying other topics, seemingly unrelated to these questions of ritual landscape, connections between the Khanty world models, gods and people's behaviour continued to emerge as factors that influence any practice among the Khanty people. I have documented these pieces of information in different contexts and now I aim to analyse the understanding of ritual landscape of the Khanty in a more concentrated way.

The method for my analysis is based on thick interpretation of my field experience (observation and interviews). In the context of my own empirical data, as well as comparative descriptions from other scholars, I test theoretical claims about the ambivalent relationship between mythic imagination in folk religion and people's actual ritual behaviour. In general, I apply the method of hermeneutic interpretation, which enables me to neglect understanding of inconsistencies in data that are the results of irrationality or fundamental cultural ambivalence but as reflections of structural principles of folk religion.

I intend to examine my fieldwork experience and discuss the ways in which the Khanty manage the complicated prescriptions of sacred topography both during rituals and in everyday practice. I argue that the actualisation of different versions of Khanty sacred topography depends on ritual practice. Rituals relating to death are modelled according to a more archaic spatial perception that is linked to tangible environmental objects (most prominently, rivers). At the same time, during reindeer offerings the Khanty switch to the concept of ritual space, which relates to cardinal directions. By dwelling on my field data, I demonstrate how distinctive indigenous spatial approaches dominate on different occasions. A comparative look at various Khanty rituals reveals several peculiarities in the spatial arrangements of these ceremonies. I intend to demonstrate that, despite this impression of ambivalence, the Khanty always apply sacred topography coherently, according to a clearly articulated approach to the relationship between the physical landscape and the mythological world understanding.

\section{MYTHS AND LANDSCAPE}

In the Khanty worldview, landscape is structured and managed by gods and spirits. According to Khanty belief, the world is divided vertically into several layers. Good, white gods rule the Upper World; the black gods of diseases and death inhabit the Lower World. It has been proposed that this mythical model of the structure of space is an archaic shared feature of Uralic cosmology. In addition, many other groups in the northern Eurasia and North America also recognise this basic model of the Universe (Karjalainen 1918: 296-298, 307; Kulemzin 1984: 170-171; Ajkhenvald et al. 1989: 157-159; Gračeva 1989; Schmidt 1989: 187; Lukina 1990: 14-16; Napolskikh 1992; 2012; Siikala 2002: 20-24; 2012: 22-24; Pyatnikova 2008: 63).

Vladislav Kulemzin (1984: 170) argues that the Khanty possibly also recognise a twolayer world model that consists of only the middle and lower worlds, thus keeping good gods (together with humans) and evil spirits in direct confrontation. The third option is to see all three worlds as self-sufficient, each one containing both good and evil spirits and gods. Valeri Chernetsov (1987: 154) and Evdokiya Rombandeyeva (1993: 19-21) propose a Mansi world model (the closest neighbours and language relatives to 
the Khanty) that includes seven layers, combined into three clusters, roughly parallel to the simpler three-level world structure. Similar data has been reported concerning the Khanty (Balalajeva and Wiget 2004: 72; Pyatnikova 2008: 63). Furthermore, in their mythical songs the Khanty sometimes describe only the Upper World as a seven-layered spatial structure (Lukina 1990: 16; Kulemzin and Lukina 1992). The most complicated ideas about the structure of the world are documented among the Vasyugan River Khanty, who consider only the lowest level of the Upper World as having seven layers (Lukina 1990: 16).

If the world is envisioned as multi-layered, parts of the Universe that stay closer to humans are inhabited by creatures that have potentially closer connections with living beings. The lower layers of the Upper World are reserved for helping spirits who serve as negotiators and messengers between gods and humans. At the same time the spirits of deceased people dwell in the upper parts of the Lower World. As a rule, people are not supposed to communicate with the main god Numi Torum directly during their prayers but turn towards these lower level messenger gods and spirits. Only in the case of a really serious crisis can prayers be sent directly to Numi Torum. At the same time, the main god does not live at the highest level of the Upper World as two layers in the top of the Upper World are reserved for Numi Torum's father Num Kurys and grandfather Num Sives. According to Khanty belief, people have no contact with these creatures, it is enough to know that somebody superior is also watching over the deeds of the supreme god. (Lukina 1990: 16)

The vertical structure of the world is experienced in a tangible way, at least in some parts of space closer to the scene of human action. The Khanty define these worlds through objects or subjects of the environment that are visible or touchable to humans. For example, the lower layers of the Upper World are labelled "the top of the birchcovered hill in the middle of the sky" or "the pine tree bog in the middle of the sky" (ibid.: 16). Analogues between the life-worlds of gods and humans are also emphasised in the Khanty myth that tells that the main god Numi Torum lives simply in "the heavenly forest" (ibid.: 73).

This vertical model of the world is also projected horizontally on to the actual landscape. The horizontal mode of sacred landscape makes ritual practices intriguing and complicated to interpret in scholarly discourse. Humans stand always in the middle point of the world. But different modes of structuring space may seemingly contradict each other. This is to be expected if we think about a variety of options for conceptualising space according to Khanty vernacular religion.

For the Khanty, forest landscapes with a multitude of waterways represent probably the most archaic layer of religious imagery (Kulemzin 1984: 171; Lukina 1990: 16; Siikala 2002: 19). Everything that is situated towards the upper streams of rivers belongs to the domain of the white gods of the Upper World and territories remaining downstream constitute the arena for the Lower World's black gods' actions. Entrance to the Lower World is situated at the mouth of the River Ob, in the Arctic Ocean. This frame of the world is intertwined with another way of structuring the space around people. Simultaneously to the up- and downstream system gods are divided in space according to the trajectory of the Sun. In this way, white gods live in the southern or eastern part of the world and the black gods of death and disease in the north or west (see overview of relevant approaches in Kulemzin 1984: 170-172; Siikala 2002: 21-22). This double sys- 
tem of categorising space is even more complicated as a result of migrations and shifts in religious ideas:

Regional world-concepts were projected horizontally onto specific geographical locations - and they clearly constituted a system of specified cult centres. During the reconstructions, two contrasting principles of the changes caused by the migrations are to be taken into account. On the one hand, the migrating sections of the people took with them their guardian spirits; on the other hand, the geographically outstanding sacred places remained, with only the character of the spirits residing over them changing in the course of the migrations. (Schmidt 1989: 226)

It appears that the Khanty treat the relationship between gods and landscape differently depending on the rank of various gods. The tendency to relate higher, sky gods to particular locations is important both from general and regional perspectives. Spiritually structured landscape enables the Khanty to specify the presence of gods and actualise their mythic world order. But this spatial connection of gods and humans also shapes ritual behaviour during everyday practices and sacred feasts. (Schmidt 1989: 223-227; Siikala 2012: 33)

Landscape is given to the Khanty by the gods (see Karjalainen 1918: 298-307; Lukina 1990: 14). The overall structure of space is designed according to the total set of divine relationships. Local sacred places are shaped by gods' particular actions. Everything around people is a result of some sacred action, conducted by gods and spirits. Although this general scheme is shared by different Khanty groups and distributed widely among the peoples of the north, specific ritual practices, related to landscape, may be more challenging to analyse in a unanimously comprehensive way.

Myths can be approached as cultural discourse but also as cultural practice. In the latter case, a myth serves "as a tool of people's social action" (Siikala 2012: 34-35). In the course of human lives, relevance in the context of everyday actions justifies the existence of myths and gods. There is a multitude of rules for ritually shaped behaviour that people feel are almost natural. Most of the Khanty are used to some basic set of sacred spatial arrangements. The vertical model of the world is good to think and sing about, while during rituals, the horizontal structure of sacred space enables the Khanty to arrange communication with gods and spirits.

The double approach to the gods' landscape (as related simultaneously to rivers and the sun) has a potential for causing some confusion. Rivers flow in different directions and upper places are not always situated to the south. Syllogistic logic says that there must be a few problems with arranging ritual behaviour in some situations. In fact, this twofold arrangement of sacred landscape never obstructs ritual actions.

Sometimes, the Khanty gods and spirits behave unpredictably. They do not always react properly to people's requests but, at the same time, can be negotiated, even manipulated. One must consider the possibility that gods can also manipulate humans. As I learned during my field trips, the Khanty occasionally complain that gods play tricks on them by pretending not to be available. The Khanty imagine the Upper World as the office of a director of a huge corporation where nobody actually cares about the needs of the common people (FM 1992; see also Karjalainen 1918: 37).

Not only do gods have the right to interpret people's prayers by disregarding the idea of a request or reacting to them selectively, but humans too are allowed to treat 
gods and spirits creatively. The relationships between inhabitants of different worlds are open-ended on every occasion. Siikala (2002: 30) advocates an idea about a fluid set of mythic rules:

The continuing negotiative process concerning the mythic-historical tradition leaves room for the creative imagination, which uses doubt and deviation as well as stereotypic reproduction, borrowed elements and their assimilation and adaptation to produce unique performances and new forms of art relevant to the present day.

In post-Soviet social settings, this communication with the gods starts to touch upon wider social processes and a range of political actors. Siikala, again, refers to this transformation of an intimate traditional ritual sphere into the space of public political manifestations. According to Siikala (2012: 35), people connect themselves with mythical events from the past through narratives and sacred sites that "possess power to unite communities and to act as a tool for national self-determination and for political interests". This myth-based flexibility reflects the adaptive functions of the Khanty worldview and makes it possible for people to modify their survival strategies. For example, negotiations with gods serve as a model for managing problems that people encounter when communicating with legislative, administrative and economic agents.

The national and political agendas of the Khanty leaders when arranging sacrificial ceremonies are usually rather vague, although not absent. The fact is that some of the Khanty rituals become public and more advertised, as well as connected to contemporary economic and social problems (see Leete 1997; 1999; 2004; 2014). At the same time, even rituals arranged for show consist of coherent authentic structure of actions and take into account the landscape of the gods.

In order to delve more deeply into the problems of the application of concepts related to sacred topography, I present three case studies from my own ethnographic field experience. These cases involve a couple of public collective sacrificial rituals with a rather different frame of arrangements, and thirdly, I am going to discuss an example of using the three-component world model in more commonplace circumstances.

\section{SACRED TOPOGRAPHY OF NUM-TO LAKE}

In April of 1996, a collective sacrificial ceremony was organised at Num-to Lake ${ }^{4}$ in the middle of Western Siberia. The Khanty and Forest Nenets consider Num-to the most holy place and sacrifice reindeer there regularly. This time, the ritual was arranged within a more political framework as part of protests against oil company developments in the region. Three reindeer were sacrificed to the gods of the Upper World in order to ask for divine support against oil drilling in the area. In order to give more publicity to the event, local TV Company Yughoria recorded the event and later broadcasted it nationwide. (For a more detailed description of the ritual, see Leete 1997; 1999.)

After the ritual, I interviewed local Khanty Stepan Randymov (1941-2005). I chose him as a key informant for the case because during the ritual I got the impression that Stepan was observing very carefully the course of action and seemed to have a rather precise idea of the different elements of the ritual. He brought up the topic of local 
sacred topography in several contexts. I got the impression that his views on details of the sacrifice were rather elaborate and suitable for generating discussion concerning the relationship between the ritual and landscape. Firstly, he discussed the shape of the sacred lake as being meaningful for the religious imagination of the local people:

On that lake there is an isthmus that looks like a human or animal neck with a head on it. On the head part there are two sacred sites. No women has ever been there. It has two eyes, two islands with six birches on them, there are two eyes on the sacred lake. In the lake, at a distance of four kilometres from the village, there is an island that is considered the heart of the lake. Women have never been to it: only men go there. ${ }^{5}$ When one sees it from a bird's eye view, from a plane or helicopter, it resembles an animal, with a heart, head, and eyes. Over there one can see plaits: small rivers go like plaits. (FM 1996)

This kind of anthropo- or zoomorphic vision empowers the vernacular feeling of the exceptional sacredness of the place, reflecting perception of landscape as a living creature on its own. In addition, it may be that these human- and animal-like qualities help to establish smooth contact with the gods, or that the location embodies a heavenly being.

Another issue, rather central to the success of the ritual, was the way in which everything was positioned during the sacrificial ceremony. Stepan addressed this topic of directing sacrificial animals and people very carefully. According to him, during any ritual related to the Upper World, reindeer and people must stand with their faces toward the sun and white heavenly gods. If anybody chooses to make a sacrifice to the black gods, everything has to be arranged in the opposite way to face the dawn.

As Stepan revealed, one can communicate with the Lower World everywhere, but the Upper World can be reached only at certain locations where access to the white gods is closer. One cannot pray to white gods in a village in mundane conditions. Stepan seemed to consider the relationship between different gods delicate to handle for humans. It is easy to make a mistake and direct your ritual message to the wrong part of the cosmic landscape. A wrong action (misdirecting a sacrificial animal during a ritual) can change the character of a ceremony completely, despite the place where the offering is made. From Stepan's discussion it appeared that the details of the offering ritual are rather similar in the case of white and black gods. One simply needs to consider the difference in the colour symbolism. Stepan emphasised that collective rituals to the white gods can be performed in special places where women must be kept away:

There are also some sites where only men are allowed to go. These are high places. They climb to some hill, and - Oh! There is a sacred site over there above the forest. However, when riding a reindeer sledge, the sacred site may be at a distance of 40-50 kilometres. In most cases such places are near the upper courses of rivers or between rivers. There are such places near here, by the Kazym River, and some other places, where it is taboo for women to go. ${ }^{6}$ (FM 1996)

The Num-to Lake area is widely recognised as a sacred location. Khanty and Forest Nenets people from other regions also go to this area to perform reindeer sacrifices (Leete 1997: 39-40; Sokolova 2009: 596; Moldanov 2010: 48-51). In addition to the overall sacredness of the area, the ritual was connected to the topography of the Khanty 
and Forest Nenets worldview through the positioning of food, people and sacrificial animals during the ceremony. Scholars commonly assume that the Khanty always orient reindeer sacrifices toward the sun, a practice that is framed by understanding of the Higher and Lower Worlds (see, for example, Karjalainen 1900: 48, 445; Balzer 1999: 188; Wiget and Balalaeva 2011: 127-133). This setting imitates indigenous approach to the structure of the world as it appears on the actual landscape - the Upper World is in the southern direction and the Lower World in the northern.

\section{SACRIFICIALRITUAL IN RUSSKINSKAYA VILLAGE}

In June 1993, I participated in another Khanty public sacrificial ritual in Russkinskaya village on the Tromyugan River. The reindeer offering ceremony took place during the fourth International Finno-Ugric Peoples' Folklore Festival and was labelled The Party of Torum. ${ }^{7}$ Hundreds of tourists participated in the event as guests, an international audience that consisted primarily of Hungarians, Finns and Estonians. (Leete 2004: 128)

The ceremony was held as a show-off event as there was no particular reason for the Khanty to sacrifice reindeer that day, but as regional administrators forced the Khanty to celebrate, they could not escape the event. In addition, the ritual site was not genuine but constructed near the village especially for the festival. A brand new sacred storehouse and a conical tent were assembled, and a fireplace and wooden frame for drying fish had been built in order to give us the impression of an authentic Khanty forest camp (Russkinskaya itself is a Soviet-style modern village without the looked-for aura of authenticity).

Seven reindeer were brought to the village from the taiga by helicopter and three shamans were captured and required to perform the ritual (one of these shamans, Sergey Kechimov, managed to escape and a random Khanty man was put into the line of shamans). Next day some policemen beat up these shamans and unknown persons destroyed the short-lived sacred site during the same night. This was revenge, demanded by the Surgutneftegaz Oil Company because the shamans had refused to sign licenses for oil exploration on their tribal territories (Balzer 1999: 153). ${ }^{8}$ Although the Khanty did not initiate the ritual, it was necessary for shamans to perform it. Among the Khanty, shamans must carry out collective sacrificial ceremonies (see Georgi 2007 [1799]: 115; Karjalainen 1900: 31; 1918: 163, 236-242, 440-441; Kulemzin 1984: 113; Barkalaja 1999: 59; Balalajeva and Wiget 2004: 81-82; Nakova 2008: 82-83; Sokolova 2009: 596; Wiget and Balalaeva 2011: 126). At the same time, between the Eastern Khanty (to whom the Tromyugan River Khanty also belong), most sacrificial rituals have nevertheless been performed without a shaman (Kulemzin 1984: 113); elders of collective sacrificial ceremonies can be elected amongst the most honoured members of a local community (Barkalaja 1997: 63; 1999: 60).

Guests left the scene after the attractive part of the ritual (the prayers and reindeer sacrifice) was over, although the Khanty had still carried out the several-hour-long ritual as correctly as they could under the circumstances. Through prayers the Khanty asked for very general support from the upper gods. As my Khanty friend explained, they requested the gods to "protect life". .9 (Leete 2004: 128) 
The sacred topography of the ceremony was arranged in the way that seven reindeer and shamans stood near a small stream with their faces to the east. The audience stood behind the shamans and a passage, following the same direction, was created in the middle of the crowd. Prayers were pronounced and the reindeer souls sent eastward where the sun rises. According to Khanty spiritual geography, east is equated with the southern direction as the space for the Upper World and the heavenly gods. (Leete 2004: 128-129, 133)

Despite the rather awkward situation, the Khanty attempted to keep the ritual as close to a real one as possible. ${ }^{10}$ Among the other elements of a genuine sacrificial ceremony, spatial rules were followed. Although the random location of the ritual site put the Khanty in a complicated situation, they managed to arrange the event according to normative cultural prescriptions. So the spatial setting of the ceremony was one of many elements of the sacrifice that was meant to avoid any possible harm that a senseless ritual could cause to participants, among them, the audience.

This Russkinskaya case indicates that the sacred world structure must be manifested during any ritual, even if culturally distant officials initiate it for political reasons and the randomly chosen part of the landscape where the sacrifice happens is not especially sacred to the Khanty. Human ritual action can thus add a temporary sacred value to a landscape and enable manifestation of the Upper World in any spot of land. This conclusion contradicts Stepan Randymov's claim that the Upper World can be reached only in specific locations, while the Lower World's gods can be reached everywhere (see above). This may indicate variations in individual or group cosmological views. However, this seeming ambivalence can also be a manifestation of the obscure relationship between gods and humans that leaves, as the Khanty suppose, some space for negotiation and thus enables ad hoc changes in sacred topography.

\section{FINDING A FOREST CAMP}

I encountered a rather different experience of Khanty sacred topography in a more mundane situation. In the summer of 1995, I was conducting ethnographic fieldwork in Surgut region, on the Pim River near the town of Lyantorsk. Our team's plan was to leave the town and spend some time in a Khanty forest camp on the Ai Pim River, the tributary of the main Pim River. I missed my fieldwork companions Auli Valta and Anzori Barkalaja and was supposed to reach our Khanty friends' summer camp on my own. The next day I found the driver who had taken my friends to the forest and asked him to drop me at the same spot where he left them. When we approached the place, a rather indefinite location in the taiga, night was already approaching. The driver left with his truck and I was supposed to get to the camp. I found a path and walked until I reached an old house belonging to our Khanty friends, which I had visited a few years earlier. Unexpectedly, the whole forest camp area appeared to be abandoned.

I realized that, perhaps, the Khanty grandfather had died recently and his family moved away. According to the Khanty worldview, a forest camp where somebody dies will be taken over by the spirits of the Lower World and people must leave the place. Staying overnight in these places might be dangerous for living creatures. 
I could not stay there because Anzori had left with my sleeping bag and that night promised to be rather cold. Besides, our Khanty friends could later easily establish my whereabouts during that night. I thought they would consider me contaminated or possessed by Lower World spirits. But my problem was that I had no idea about the location of the new forest camp. It was complete darkness and totally quiet around me by that time. I attempted to listen for the Khanty dogs' barking from a new camp but there was nothing to hear. The whole forest was completely silent. I decided to follow the river and reached the new campsite six hundred meters from the former one.

Everyone in the new camp was already sleeping (including dogs) but when I arrived, the Khanty friends' family got up and we started to drink tea. After consuming three huge cups (that is a minimum for one-time tea drinking episode for the Khanty), I was supposed to tell everybody how I managed to reach the new summer camp. Eventually, I got the impression that I succeeded in earning a few credits in the eyes of the Khanty because I avoided the dead man's residence and indicated some skills in way finding.

The Khanty explained that a dead man takes his house with him and continues to live there among spirits of the Lower World. In such cases a family must move further upstream. If a women dies, it is not necessary to abandon a camp. But until there is a figures of gods and spirits of death in the house, the spirits are not able to occupy the building. Until then, it is considered to be the people's domain. In fact, our Khanty friends laughed on my stupidity during that tea session. They had not moved their kin spirits out from the old house and actually it would have been all right to stay there overnight.

The idea about spirits of the Lower World inhabiting houses of the deceased and forcing people to move upstream is widespread among the Khanty (Kulemzin 1984: 54). This custom is one among numerous practices of taking into account sacred topography in more everyday arrangements. The Khanty traditional houses and conical tents are always positioned according to directions of space. Rules that constitute genderspecific areas inside a living room and movements around campsites also take into consideration the way in which landscape is divided between different mythological worlds. The Khanty's intimate living space is penetrated and structured by the gods' landscape (Kulemzin and Lukina 1992). This close connection with sacred topography orchestrates everyday Khanty practice and gives them a persuasive rhythm of living in accord with the gods' spatial arrangements in every situation of their lives.

In the Pim River region moving a forest camp upstream away from the Lower World, in the case of a camp master's departure, means that during the death ritual, the Upper World is projected to the north and the Lower World to the south. This ritual behaviour seems to indicate an existent controversy between application of the Lower and Upper World models on landscape. According to syllogistic logic, the Upper World should not be assigned simultaneously to the south (as in the case of sacrificial ceremonies) and to the north (while performing the moving ritual after somebody dies). But our evidence seems to indicate exactly this. Apparently ambivalent ideas about situating the Lower and Upper worlds need to be discussed within the larger framework of the Khanty religion. 
The relationship between ritual and landscape can be analysed in the context of different aspects of the Khanty worldview. A few researchers have envisioned the overall representation of the Khanty religion as rather chaotic. Karjalainen (1918) noticed that nobody would ever be able to count correctly all the Ob-Ugrian gods and spirits because the data is enormous and disorganised. In addition, Kulemzin (1984: 174) deduced from a large body of evidence that the Khanty worldview is a rather "amorphous mass of religious ideas". Several scholars have expressed similar doubts about the logic of different areas of Ob-Ugrian vernacular religion. Éva Schmidt (personal communication, 1992) argued that the Khanty report different numbers of human souls and explain the functions of these souls in a variety of ways, without coherence between various views. Chernetsov claimed in the preface to his classical study of the Ob-Ugrian soul concept (1959) how the Khanty people recounted that a human consists from two to seven souls. Chernetsov proposed that, in a way these variations (between two and seven) might be simultaneously true. Kulemzin (1984: 59) notes that imagination of local spirits is rather diverse among the Khanty. For example, when analysing other-than-human beings, a scholar cannot be completely sure if the Khanty are talking about animals, objects or spirits that appear in a specific form. If the Khanty understanding of gods, spirits and souls varies open-endedly, does it make the whole vernacular religion and ritual behaviour relative and nothing can be said definitely about the Khanty worldview?

Known prototypes of the Khanty sacred landscape (the vertical and the two horizontal modes of space) seem to have a potential to contribute to this conceptual confusion in the framework of ritual practice. If the Khanty feel no contradiction here, it can be assigned to the vernacular tendency to ignore ambivalences that strike the syllogistically trained scholarly mind. I propose that the Khanty make perfect sense when applying different versions of sacred topography in their ritual action.

We can take discussions concerning the soul or other-than-human beings as a key to interpreting the relationship between landscape and ritual. Places are polyphonic "as complex as voice" and enable the localisation of concepts (Rodman 1992: 640-643). The Khanty landscape with its river flow directions and overall north-south orientation can be treated as a heterotopic "simultaneously mythic and real contestation" (see Foucault 1986 [1967]) of a meaning-making space. Although logical paradoxes seem inevitable, the Khanty manage to arrange landscape-bound rituals without hesitation. Somehow, every opinion can be correct or, at least, tolerated, and the will of gods constantly reinterpreted. But there is still an underlying cultural ideology that makes the topographical background of rituals coherent.

There is a significant difference in how presented examples of rituals illuminate the relationship between sun- and river-bounded sacred topography. Num-to Lake is situated in a higher area, several rivers flow from the region in different directions and this fact prevents the sacred topography from becoming obscure. The absence of a dominant river makes the Num-to area's divine geography clear and pure. Rituals can be oriented here only according to the directions of the world.

But the Middle $\mathrm{Ob}$ area presents a particularly interesting case for discussing the relationship between landscape-embodied cosmology and ritual action. In this region the $\mathrm{Ob}$ flows westwards and the right-hand tributaries of $\mathrm{Ob}$ to the south (as with the 
Pim and Tromyugan rivers). This means, paradoxically, that ritual orientation, related to rivers, places the Upper World to the north, in areas designated to the Lower World in regard of south-north axis of the cosmological world design. The indigenous people of this region orientate their ritual behaviour on some occasions according to rivers, ignoring the darkness-and-light paradigm of space. Therefore, ritual orientation, as relating to rivers, dominates in certain contexts the south-north sacred rule. In everyday life, one simply cannot ignore rivers, with which the gods are closely connected. This relationship between simultaneously applied seemingly ambivalent cosmological laws appears hazy, although, actually, the Khanty are pretty sure about these ritual orientations. The Khanty of Pim and Tromyugan rivers place the Upper World to the south during sacrificial ceremonies, but to north when performing movement to a new campsite after the master of a forest settlement dies.

Nevertheless, at some points it may be difficult to establish the accuracy of following sacred topographical and ritual rules, rooted in Khanty mythological narratives. We can take another look at the relationship between rivers and sacrificial rituals among the Khanty. Uuno Taavi Sirelius (1900: 22-26), Karjalainen (1918: 187), Rombandeyeva (1993: 64), Wiget and Balalaeva (2011: 126) assert that the Khanty and Mansi sacrificial places for gods and spirits are always situated near water. Siikala (2002: 22) argues that sacrificial rituals must be conducted near water as it carries the souls of deceased people and slaughtered animals to the other world. The last argument can be easily challenged, as, for example, there is no way this rule remains valid in the case of the Num-to ritual. Stepan Randymov (FM 1996) particularly stressed that the souls of reindeer go to the Upper World in the southern direction. The course of the ritual substantially confirmed this argument. However, rivers can take souls only to the Lower World (see Schmidt 1989). Even more clearly, the insufficiency of this claim about the specific role of rivers in sacrificial ceremonies is illustrated by data, offered by Wiget and Balalaeva. When describing a particular reindeer sacrifice on the ice of Tromyugan River ${ }^{11}$ in 1992, Wiget and Balalaeva (Balalajeva and Wiget 2004: 87-88; Wiget and Balalaeva 2011: 126-133) provide evidence that, despite the proximity of the south-flowing river, sacrificial reindeer were oriented eastward. But if reindeer were not directed according to the river flow, how can animal souls go with it? If the reindeer souls go to the Lower World, what was then left for the Upper World gods, to whom the Khanty prayed?

Khanty beliefs allow additional argumentation to explaining this apparent contradiction. The Khanty believe that all living beings have at least two souls, one of which moves to the Upper World and the other to the underworld in the course of a sacrificial ritual (Karjalainen 1918: 19-36, 448-462; Kulemzin 1984: 21; Balalajeva and Wiget 2004: 91). This view makes perfect sense when praying to gods of both worlds (see Barkalaja 1997: 60; Wiget and Balalaeva 2011: 131). But this reason does not hold up in the case of the Num-to ritual as people were praying there only to the Upper World gods and there was no river or stream nearby that could possibly take one of the reindeer's souls to the Lower World. Perhaps Num-to Lake could do the soul-carrying job as well.

In the Middle $\mathrm{Ob}$ region this appears to be more confusing. Barkalaja reports some cases of reindeer sacrifice on the Pim River from 1994, 1995 and 1997. During the 1994 and 1995 ceremonies the sacrificial reindeer were made to stand facing the north. At the same time white textile was wrapped around their necks. Later, many participants in the 1995 ceremony fell ill, something that was interpreted by some local Khanty as the 
result of giving too much credit to the gods of the Lower World (Barkalaja 1997: 60-65; 1999: 58). The sacrificial ritual in 1995 was a collective ceremony for all the Pim River Khanty. These large rituals had not been performed here for decades. Consequently, the organisers of the ceremony lacked experience in arranging such an event. Lost knowledge was given as an argument when people discussed the ambivalent results of the sacrifice (ibid.: 65-66). As far as I can understand Barkalaja's field data, there was no unanimous agreement among the Khanty about any mistake in the direction of the reindeer during the ceremony. A short conclusion in this respect may still be that on the Pim River, one is supposed to project the Upper World to the north (upstream) when moving a forest camp, but to the south if reindeer are sacrificed.

After the sacrificial rituals at Russkinskaya and Num-to, some of my Khanty friends expressed the opinion that these ceremonies were not real because of their political agenda and the doubtful attitude of many participants (who took part in these rituals as an excuse for alcohol consumption). However, my interviews and observations confirm that at least some of the participants took these rituals seriously. They supervised the overall correctness of the ceremonies and checked the details of ritual conduct.

One may argue that the three case studies (and randomly available comparative evidence) presented in this paper are not representative and cannot serve as the basis for adequate generalisation. Certainly, analysis of just a few episodes does not prove any overall law; however, even these few events are good enough to illuminate evident ambivalences (demonstrating that overall rules can be challenged on particular occasions) and enable a inductive hypothesis that can be tested on a larger body of data, or in other circumstances. At the same time, these cases are not all just random incidents. The Num-to and Russkinskaya rituals serve as extreme examples of post-Soviet public sacrificial ceremonies, and evidence about these cannot be extensive. The most prominent treatments of sacred topography (during public rituals) and the most trivial example (about changing the location of a forest camp) enable significant discussion on the relationship between landscape and ritual in a more general vein.

I maintain that in the case of Khanty sacrificial rituals, the model of sacred topography that relates to the directions of space dominates the cosmology of a river. One cannot kill a reindeer without making a sacrifice (Niglas 1997: 25-26; Nagy 2011: 80). In addition, one cannot always kill a reindeer near water. This makes the argument about the compulsory relationship between sacrifice and a water body unjustified. At the same time, cardinal directions are treated in a consistent way according to south-north orientation during sacrificial rituals. But in the course of some other ritual activities, the world model represented through landscape and by rivers, can dominate the day and night pattern of cosmology.

World models structure the perception of space but are not simply varieties of intellectual exercise for the Khanty. Grand mythological narratives influence people's worldview and ritual action, although everyday discourse and communication also have an effect. Different versions of cosmological models have distinctive functions and domains in Khanty ritual practice. Coherent theoretical frameworks for constituting cultural space are frequently misleading (Ellen 2004: 104), although at least in the Khanty case there is the possibility that sacred topography is consistent and that different models of space are actualised on particular ritual occasions. 
Every episode of reindeer sacrifice is autonomous to a certain extent. Any sacrificial ritual involves a unique and self-sufficient combination of actions and meanings. A comparison of different cases and attempts to deduce general rules leads to logical contradictions. This comes about because documented empirical evidence is detailed to a different degree or appears ambivalent because different people interpret particular episodes of sacrificial ritual differently. But, also, the Khanty do not care too much about perfect abstract coherence between the spatial arrangements of different reindeer sacrifices.

A detailed examination of particular cases of ritual practice illuminate ways in which available mythic imaginations are used during specific rituals and how rituals influence understanding of mythic space. Moreover, this analysis can be used in order to reveal a shared logic of manipulating religious ideas and practices among the Khanty. Consequently, this methodological guideline, although rather vague and conditional, can be used when examining other domains of indigenous belief and ritual.

As we can see, ambivalences in understanding sacrificial rituals occur between descriptions of different authors (due to fragmentary evidence concerning distinctive case studies). In addition, discrepancies in the reports of indigenous informants cause some confusion. Informants may have a different role in these rituals and their level of indigenous knowledge may vary. But as my experience shows, for those Khanty who had active functions in rituals and who were informed enough about the rules of sacrifice, there was no disarray in these events.

Among the Khanty, therefore, there is genuine knowledge about the rules of sacrificial ceremonies. By itself this core knowledge is harmonic. Ambivalences appear during attempts to find general rules by using information obtained from informants who have different access to knowledge and while trying to deduct abstract canons from rather diverse evidence. In the case of mapping sacred Khanty topography, rituals and everyday arrangements make perfect sense if we admit the logic of the different models of cosmological order. Although Descola argues that indigenous ideas lack coherence, the Khanty's sacred topography is intrinsically systematic and not just because of a scholarly approach that searches for regularities. It may well be that this functional integrity is related to tangible qualities of landscape (as Malinowski suggests). By following Ingold's statement, I assert that the Khanty are born into sacred topography. The Khanty imitate mythic landscape during their rituals and reproduce it in the same process. In other areas of folk religion with less tangible qualities, variations and discrepancies of vernacular interpretations may be more substantial.

Following on from this, one must be rather cautious when arguing about ambivalences in folk religious practice. Consistent interpretation of data sometimes reveals cultural rules behind seemingly contradictory empirical data. Of course, similar discretion must be applied regarding arguments in favour of harmony between views on sacred topography and actual ritual practice. In general, arguments favouring fragmentarity and ambivalence stand, but in the specific case of Khanty sacred topography, evidence supports cultural arrangements having a coherent logic. 


\section{NOTES}

1 I use 'worldview' as the basic term and 'mythic world perception' and 'mythic imagination' as synonyms for it. As regards the problems discussed in this paper, the topic is always related to the mythic component of worldview. One can also find the term 'beliefs' here, by which I mean particular conceptual manifestations of the Khanty worldview.

2 By the term 'sacred topography' I mean a particular myth-based mode the Khanty people have of imagining plots of land. 'Spatial representations', 'spatial models', 'sacred landscape' and 'ritual landscape' designate similar concepts but in a more tangible context. At the other end of the scale, 'sacred geography' and the 'mythical model of the structure of space' have a wider and more abstract meaning, referring to a general relationship between the understanding of space and the physical landscape among the Khanty. Even more general are notions of the 'cosmological model', 'cosmological scheme' and 'mythic world order' that mark the overall conception of the structure of space that provides content to the sacred landscape.

3 During my fieldwork trips, I worked among the Eastern Khanty in Surgut rayon (Pim River), as well as among the Northern Khanty in Beloyarsk rayon (the Kazym River and Num-to regions) and Priuralsk rayon (the lower course of the Ob River).

4 Num-to - 'heavenly lake' or 'Lake of God' in Nenets; in the Khanty language Torum lor.

5 In December of 1933 a Russian woman, Polina Shnaider, a representative of the Ob-Irtysh oblast party committee, went there and was killed (with other officials) by local Khanty and Forest Nenets. This action was among the main reasons for the armed uprising undertaken by the local Khanty and Forest Nenets people against the Soviet regime in 1933-1934.

6 Timofey Moldanov (2010: 49) reports that women's attendance has spoiled the small sacred island at the shore of Num-to Lake. Because of that, the sacred place is now abandoned.

7 Torum, Torem ('god' or 'heaven' in the Khanty language) can be any god in the Khanty cosmology; here the main god Numi Torem ('heavenly god' in the Khanty language) is meant.

8 Even today, more than 20 years later, the Surgutneftegaz oil company has not settled the oil drilling licenses with Sergey Kechimov, the shaman who escaped the Russkinskaya ritual in 1993 (see Favorsky 2015; IWGIA 2015).

9 During the 1996 Num-to ceremony, people also prayed for general smoothness of life (political statements stood apart from the sacrificial ceremony as such). Today this kind of general prayer about health, happiness and prosperity are rather common for Khanty sacrificial rituals, as shown by the evidence provided by Andrew Wiget and Olga Balalaeva (Balalajeva and Wiget 2004: 69, 86-87; Wiget and Balalaeva 2011: 119, 131). Kustaa Fredrik Karjalainen (1918: 136) reports that already in the 18th century Khanty sacrifices with this general aim were documented. So it seems to be a rule that collective prayers target general prosperity and happiness.

10 For a more detailed description of the sacrificial ritual, see Leete 2004.

11 According to Timofey Moldanov, it is prohibited to step on ice during a sacrificial ritual (2010: 48). Here we can observe another variety (or seeming contradiction) of sacred rules, related to Khanty rituals and places. 


\section{SOURCES}

FM = fieldwork materials of the author, 1992-1996.

\section{REFERENCES}

Ajkhenvald, Aleksandra; Eugene Helimski, and Vladimir Petrukhin. 1989. On Earliest FinnoUgrian Mythologic Beliefs: Comparative and Historical Considerations for Reconstruction. - Uralic Mythology and Folklore. Ethnologica Uralica 1, edited by Mihály Hoppál and Juha Pentikäinen. Budapest; Helsinki: Ethnographic Institute of the Hungarian Academy of Sciences; Finnish Literature Society, 155-159.

Anttonen, Veikko. 1996. Ihmisen ja maan rajat. 'Pyhä' kulttuurisena kategoriana. Suomalaisen Kirjallisuuden Seuran toimituksia 646. Helsinki: SKS.

Appleby, R. Scott. 2000. The Ambivalence of the Sacred: Religion, Violence, and Reconciliation. Lanham, MD: Rowman \& Littlefield Publishers.

Balalajeva, Olga and Andrew Wiget. 2004. Handi kollektiivne põdraohverdus: usk, olemasolu ja kultuuriline püsimajäämine tänapäeva Siberis. - Mäetagused 26: 69-103. DOI: https://doi. org/10.7592/MT2004.26.ohverdus.

Balzer, Marjorie Mandelstam. 1999. The Tenacity of Ethnicity: A Siberian Saga in Global Perspective. Princeton, NJ: Princeton University Press.

Barkalaja, Anzori. 1997. On the Sacrificial Ritual of the Pim River Khanty in December 1995. - Pro Ethnologia 5: 57-68.

Barkalaja, Anzori. 1999. On the Sacrificial Rituals of the Pim River Khanties: Part Two. - Pro Ethnologia 8: 57-72.

Chernetsov, Valeriy Nikolayevich. 1959. Predstavleniye o dushe u obskikh ugrov. - Trudy Instituta Etnografii, n. s., 51. Moskva; Leningrad: AN SSSR, 114-156. [Чернецов, Валерий Николаевич. 1959. Представление о душе у обских угров. - Труды Института Этнографии, н. с., 51. Москва; Ленинград: АН СССР, 114-156.]

Chernetsov, Valeriy Nikolayevich. 1987. Istochniki po etnografii Zapadnoy Sibiri. Tomsk: Izdatel'stvo Tomskogo universiteta. [Чернецов, Валерий Николаевич. 1987. Источники по этнографии Западной Сибири. Томск: Издательство Томского университета.]

Descola, Philippe. 2004. Constructing Natures: Symbolic Ecology and Social Practice. - Nature and Society: Anthropological Perspectives, edited by Philippe Descola and Gísli Pálsson. London; New York, NY: Routledge, 82-102.

Doniger, Wendy. 1995. Foreword. - Claude Lévi-Strauss. Myth and Meaning. New York, NY: Schocken Books, vii-xv.

Ellen, Roy F. 2004. The Cognitive Geometry of Nature: A Contextual Approach. - Nature and Society: Anthropological Perspectives, edited by Philippe Descola and Gísli Pálsson. London; New York, NY: Routledge, 103-123.

Favorsky, Maria. 2015. The Old Man and the Sea of Oil. - Greenpeace International. http://m.greenpeace.org/international/en/high/news/Blogs/makingwaves/russian-taiga-lake-imlor-oil-drilling/blog/53825/ (accessed March 6, 2016).

Foucault, Michel 1986 [1967]. Of Other Spaces. - Diacritics 16: 22-27. DOI: https://doi. org $/ 10.2307 / 464648$.

Georgi, Iogann-Gotlib. 2007 [1799]. Opisaniye vsekh obitayushchikh v Rossiyskom gosudarstve narodov: ikh zhiteyskikh obryadov, obyknoveniy, odezhd, zhilishch, uprazhneniy, zabav, veroispovedaniy i drugikh dostoprimechatel'nostey. Sankt-Peterburg: Russkaya simfoniya. [Георги, ИоганнГотлиб. 2007 [1799]. Описание всех обитающих в Российском государстве народов: их 
житейских обрядов, обыкновений, одежд, жилищ, упражнений, забав, вероисповеданий и других достопримечательностей. Санкт-Петербург: Русская симфония.]

Gottowik, Volker. 2014. Introduction. - Dynamics of Religion in Southeast Asia: Magic and Modernity, edited by Volker Gottowik. Amsterdam: Amsterdam University Press, 9-29.

Gračeva, Galina N. 1989. Nganasan Shaman's Ways and Worldview. - Uralic Mythology and Folklore. Ethnologica Uralica 1, edited by Mihály Hoppál and Juha Pentikäinen. Budapest, Helsinki: Ethnographic Institute of the Hungarian Academy of Sciences; Finnish Literature Society, 233-238.

Harwood, Frances. 1976. Myth, Memory, and the Oral Tradition: Cicero in the Trobriands. American Anthropologist 78: 783-796. DOI: https://doi.org/10.1525/aa.1976.78.4.02a00040.

Ingold, Tim. 2002. The Perception of the Environment: Essays on Livelihood, Dwelling and Skill. London; New York, NY: Routledge.

IWGIA 2015 = Russia: Guardian of Khanty sacred lake facing prison for defending himself against stray dogs brought in by oil workers. http://www.iwgia.org/news/search-news?news_id=1232 (accessed March 6, 2016).

Karjalainen, Kustaa Fredrik. 1900. Ostjakkeja oppimassa. Matkakirjeitä. - Suomalais-Ugrilaisen Seuran Aikakauskirja XVII: 1-74.

Karjalainen, Kustaa Fredrik. 1918. Jugralaisten uskonto. Suomensuvun uskonnot III. Porvoo: Werner Söderström osakeyhtiö.

Kulemzin, Vladislav Mikhaylovich. 1984. Chelovek i priroda v verovaniyakh khantov. Tomsk: Izdatel'stvo Tomskogo universiteta. [Кулемзин, Владислав Михайлович. 1984. Человек и природа в верованиях хантов. Томск: Издательство Томского университета.]

Kulemzin, Vladislav Mikhaylovich and Nadezhda Vasil'yevna Lukina. 1992. Znakom'tes': Khanty. Novosibirsk: Nauka. http://groh.ru/map/hant/hant.html\#3 (accessed March 7, 2016). [Кулемзин, Владислав Михайлович; Надежда Васильевна Аукина. 1992. Знакомьтесь: Хантьы. Новосибирск: Наука. http://groh.ru/map/hant/hant.html\#3]

Leete, Art. 1997. Sacrificial Ceremony at Lake Num-To. - Pro Ethnologia 5: 35-55.

Leete, Art. 1999. Ethnopolitical Comments About the Sacrificial Ceremony At Lake Num-To. - Pro Ethnologia 7: 21-26.

Leete, Art. 2004. Ritual, Politics and Mentality: The Nenets and Ob-Ugrians of Siberia. - Creating Diversities: Folklore, Religion and the Politics of Heritage, edited by Anna-Leena Siikala and Stein Mathisen. Helsinki: Finnish Literature Society, 125-135.

Leete, Art. 2014. Sacrifices de rennes et pétrole: dialogue entre rituel et droits des peuples autochtones. - Études finno-ougriennes 46: 57-88.

Lévi-Strauss, Claude. 1995 [1979]. Myth and Meaning. New York, NY: Schocken Books.

Lukina, Nadezhda Vasil'yevna. 1990. Predisloviye. - Mify, predaniya, skazki khantov i mansi, compiled by N. V. Lukina, edited by E. S. Novik. Moskva: Nauka, 5-58. [Дукина, Надежда Васильевна. 1990. Предисловие. - Мифы, предания, сказки хантов и манси, сост. Н. В. Аукина, (под. ред.) Е. С. Новик. Москва: Наука, 5-58.]

Lunaček, Izar. 2004. The Good, the Bad and the Outcast: On the Moral Ambivalence of Folk Heroes. - Studia Mythologica Slavica 17: 207-219.

Malinowski, Bronislaw. 1922. Argonauts of the Western Pacific. London: Routledge.

Malinowski, Bronislaw. 1954 [1926]. Magic, Science and Religion and Other Essays. Garden City, NY: Doubleday \& Co., Inc.

Moldanov, Timofey. 2010. Obshchiye mesta provedeniya obryadov lesnykh nentsev i kazymskikh khantov (po dannym fol'klora). - Timofey Moldanov, Tat'yana Moldanova. Ocherki traditsionnoy kul'tury khantov: izbrannoye by. Khanty-Mansiysk: OOO Tipografiya "Pechatnoye delo", 48-52. [Молданов, Тимофей. 2010. Общие места проведения обрядов лесных ненцев и казымских хантов (по данным фольклора). - Тимофей Молданов, Татьяна Молданова. 
Очерки традиционной культуры хантов: избранное, Ханты-Мансийск: ООО Типография «Печатное дело», 48-52.]

Nagy, Zoltan. 2011. Vasyuganskiye khanty. Izmeneniye religioznoy sistemy v XIX-XXI vekakh. Tomsk: Izdatel'stvo Tomskogo gosudarstvennogo pedagogicheskogo universiteta. [Надь, Золтан. 2011. Васюганские ханты. Изменение религиозной системы в ХІХ-ХХІ веках. Томск: Издательство Томского государственного педагогического университета.]

Nakova, Yu. 2008. Kompleks obryadov pokloneniya na obshchikh kul'tovykh mestakh khantov Yamalo-Nenetskogo okruga. - Mifologiya khantov: Materyaly nauchno-prakticheskogo seminara, posvyashchennogo 50-letiyu kandidata istoricheskikh nauk T. A. Moldanovoy. 21-25 maya 2007 goda g. Khanty-Mansiysk, edited by Tat'yana Aleksandrovna Moldanova. Khanty-Mansiysk: Poligrafist, 79-84. [Накова, Ю. 2008. Комплекс обрядов поклонения на общих культовых местах хантов Ямало-Ненецкого округа. - Мифология хантов: Матеряль научно-практического семинара, посвященного 50-летию кандидата исторических наук $T$. А. Молдановой. 21-25 мая 2007 года г. Ханты-Мансийск, под. ред. Татьяна Александровна Молданова. Ханты-Мансийск: Полиграфист, 79-84.]

Napolskikh, Vladimir. 1992. Proto-Uralic World Picture: A Reconstruction. - Northern Religions and Shamanism. Ethnologica Uralica 3, edited by Mihály Hoppál and Juha Pentikäinen. Budapest; Helsinki: Akadémiai Kiadó; Finnish Literature Society, 3-20.

Napolskikh, Vladimir. 2012. The Earth-Diver Myth (A812) in Northern Eurasia and North America: Twenty Years Later. - Mythic Discourses: Studies in Uralic Traditions. Studia Fennica Folkloristica 20, edited by Frog, Anna-Leena Siikala and Eila Stepanova. Helsinki: Finnish Literature Society, $120-140$.

Niglas, Liivo. 1997. Reindeer in the Nenets Worldview. - Pro Ethnologia 5: 7-33.

Pálsson, Gísli. 2004. Human-Environmental Relations: Orientalism, Paternalism and Communalism. - Nature and Society: Anthropological Perspectives, edited by Philippe Descola and Gísli Pálsson. London; New York, NY: Routledge, 63-81.

Pyatnikova, T. R. 2008. Mifologicheskoye predstavleniye o "verkhnem mire". - Mifologiya khantov: Materyaly nauchno-prakticheskogo seminara, posvyashchennogo 50-letiyu kandidata istoricheskikh nauk T. A. Moldanovoy. 21-25 maya 2007 goda g. Khanty-Mansiysk, edited by Tat'yana Aleksandrovna Moldanova. Khanty-Mansiysk: Poligrafist, 63-68. [Пятникова, Т. Р. 2008. Мифологическое представление о «верхнем мире». -Мифология хантов: Матеряль научно-практического семинара, посвященного 50-летию кандидата исторических наук $T$. А. Молдановой. 21-25 мая 2007 года г. Ханты-Мансийск, под. ред. Татьяна Александровна Молданова. Ханты-Мансийск: Полиграфист, 63-68.]

Rodman, Margaret C. 1992. Empowering Place: Multilocality and Multivocality. - American Anthropologist 94 (3): 640-656. DOI: https://doi.org/10.1525/aa.1992.94.3.02a00060.

Rombandeyeva, Evdokiya Ivanovna. 1993. Istoriya naroda mansi (vogulov) i ego dukhovnaya kul'tura (po dannym fol'klora i obryadov). Surgut: Severnyy dom. [Ромбандеева, Евдокия Ивановна. 1993. История народа манси (вогулов) и его духовная культура (по данным фольклора и обрядов). Сургут: Северный дом.]

Schmidt, Éva. 1989. Bear Cult and Mythology of the Northern Ob-Ugrians. - Uralic Mythology and Folklore. Ethnologica Uralica 1, edited by Mihály Hoppál and Juha Pentikäinen. Budapest; Helsinki: Ethnographic Institute of the Hungarian Academy of Sciences; Finnish Literature Society, 187-232.

Siikala, Anna-Leena. 2002. What Myths Tell about Past Finno-Ugric Modes of Thinking. - Myth and Mentality: Studies in Folklore and Popular Thought. Studia Fennica Folkloristica 8, edited by Anna-Leena Siikala. Helsinki: Finnish Literature Society, 15-32.

Siikala, Anna-Leena. 2012. Myths as Multivalent Poetry: Three Complementary Approaches. Mythic Discourses: Studies in Uralic Traditions. Studia Fennica Folkloristica 20, edited by Frog, Anna-Leena Siikala and Eila Stepanova. Helsinki: Finnish Literature Society, 17-39. 
Sirelius, Uuno Taavi. 1900. Ostjakkilaiselta matkaltani v. 1898. - Suomalais-Ugrilaisen Seuran Aikakauskirja XVII: 1-29.

Sokolova, Zoya Petrovna. 2009. Khanty i mansi: Vzglyad iz XXI veka. Moskva: Nauka. [Соколова, Зоя Петровна. 2009. Ханты и манси: Взгляд из ХХІ века. Москва: Наука.]

Taringa, Nisbert. 2006. How Environmental Is African Traditional Religion? - Exchange 35 (2): 191-214. DOI: https://doi.org/10.1163/157254306776525672.

Valk, Ülo. 2008. Inimene ja teispoolsus eesti rahvausundis. - Eesti Rahvakultuur, edited by Ants Viires and Elle Vunder. Tallinn: Eesti Entsüklopeediakirjastus, 379-395.

Wiget, Andrew and Olga Balalaeva. 2011. Khanty, People of Taiga: Surviving the Twentieth Century. Fairbanks, AK: University of Alaska Press. 